\title{
Formulating Oil Palm Investment Decision in Tidal Wetlands of South Sumatra, Indonesia
}

\author{
ELISA WILDAYANA \\ Faculty of Agriculture, Sriwijaya University, South Sumatra, Indonesia,
}

\begin{abstract}
The research aimed to formulate an investment decision for oil palm plantation in tidal wetlands of PulauRimau, Banyuasin South Sumatra Indonesia. The research summarized that Land productivity and input amount will determine some differences of each soil suitability $\left(\mathrm{S}_{1}, \mathrm{~S}_{2}\right.$ and $\left.\mathrm{S}_{3}\right)$. The more land suitability level is, the more Fresh Fruit Bunches of Oil Palm (FFB) productivity per ha is produced and the less input is given. Net B/C Ratio, NPV and IRR for all land suitability classes are financially feasible for oil palm plantation development, however the most feasible and the most Expected Rate of Return (IRR) is in tidal wetlands with $S_{1}$ land suitability (very suitable), followed by $S_{2}$ (suitable) and $S_{3}$ (marginally suitable). Sensitivity analysis to feasibility for three land suitability is still economically feasible to build and to develop oil palm plantation, especially in large scale, thus its decision for capital investment is suitable.
\end{abstract}

Keywords:Formulating, oil palm, investment decision, tidal wetlands, South Sumatra

\section{INTRODUCTION}

After four decades, approximately 40,263 ha of PulauRimau, Banyuasin South Sumatra has been reclaimed and cultivated for food crops (such as rice, corn and cassava). Field and laboratory data indicated that the reclaimed PulauRimau wetlands are less suitable for food crops. A lot of constraints for plant growth of food crops are found, such as water-saturated rooting zone (anaerobic layers), the presence of pyrite $\left(\mathrm{FeS}_{2}\right)$, lowto very low soil fertility, the presence of deep peat, excessive waterlogging and impacts of sea water intrusion (salinity). Management of pyrite soils and peat soils are difficult and if wetlands are mismanaged, then they cannot be planted again because of high soil acidity (Armanto, 2014).

The main failure factors are that they are "less understood of their characters and properties either in the spatial or attribute

Correspondence: Elisa Wildayana, Faculty of Agriculture, Sriwijaya University, South Sumatra, Indonesia,

Phone/Fax +62711820933 HP. +628127338950,

Email: ewildayana@unsri.ac.id performance forms", so the reclamation programs tended to force their biophysical conditions to be suitable for certain plant growth and production. Efforts to neutralize the acidity of soils will be very expensive and take a long time (Wildayana, 2013). Management of proper drainage system is needed in order to achieve optimum soil moisture for plants and to prevent the emergence of acid sulfate to the surface and not excessively drought. Therefore, it is needed to determine the cropping pattern and water management strategies by using data of groundwater level fluctuations (Wildayanaet al., 2012).

Although the problems are complicated (complex), it does not shrink entrepreneurs, farmers and government to continue to take advantage of using Pulau Rimau for industrial plants, especially for oil palm. The development of oil palm large-scale plantations is sometimes not accompanied by careful planning and good technical knowledge, especially in relation to land suitability. This study aims to formulate oil palm investment decision in tidal wetlands of South Sumatra, Indonesia and to analyze their financial investment in various types of land suitability and to establish the suitability of 
most financially feasible for investment decisions in oil palm plantations.

\section{METHODS}

The research flow chart is described in Figure 1. The land suitability method was detail field survey and interpretation of landsat TM 7 (scales of 1:250,000, multitemporal) as well as topographic maps (scale of 1:50,000). Soil characteristics were carried out by exploring transects on land units and recorded in the soil profile cards (Soil Survey Staff, 2014). The soil samples were taken for lab analysis. The production data was made by squares methods, i.e. $25 \times 25 \mathrm{~m}$.

Some formulas for financial investment feasibility are described as follows:

1. Investment Cost (BI, Rp/ha) ..... (1)

$\mathrm{BI}=\mathrm{Btbm}+\mathrm{Badm}+\mathrm{Bnt}+\mathrm{Bhgu}+\mathrm{Bidc}$

Where:

Btbm = Cost of unproductive plant (Rp/year)

Badm = Administrative and general cost (Rp/year)

Bnt $=$ Cost of not plant $(\mathrm{Rp} / \mathrm{ha})$

Bhgu $=$ Cost of property $(\mathrm{Rp} / \mathrm{ha})$

Bidc $=$ Interest cost during period of investment (Rp/year)

2. Operational cost (Bop, Rp/year)

Bop $=$ Bpm + Badm + Bangkt

Where:

$\mathrm{Bpm}=$ Maintenance cost (Rp/year)

Badm $=$ Administrative and general cost (Rp/year)

Bangkt $=$ Transport cost $(\mathrm{Rp} /$ year $)$

3. Total cost (BT, Rp/year)

$\mathrm{BT}=\mathrm{BI}+\mathrm{BOp}+\mathrm{BBp}+\mathrm{BPjk}$

where:

$\mathrm{BI}=$ Investment cost (Rp/year)

Bop $=$ Operational cost $(\mathrm{Rp} /$ year $)$

$\mathrm{BBp}=$ Interest cost of loan (Rp/year)

$\mathrm{BPjk}=$ Income tax $(\mathrm{Rp} / \mathrm{year})$

4. Revenue (Pn, Rp/year)

$\mathrm{Pn}=\mathrm{Y} \times \mathrm{Hy}$

where:

$$
\begin{aligned}
& \mathrm{Y}=\text { Sold price }(\mathrm{Rp} / \mathrm{kg}) \\
& \mathrm{Hy}=\text { Production }(\mathrm{kg} / \mathrm{ha} / \text { year })
\end{aligned}
$$

To determine the suitability of alternative land for palm oil is the most financially feasible to do calculations and analysis using the formula:

a. Net B/C

Net $\mathrm{B} / \mathrm{C}=\frac{\sum P V N e t \text { Benefityangpositif }}{\sum P V N e t B e n e f i t y a n g n e g a t i f}$

b. Net Present Value (NPV)

NPV $=$ PV Benefit - PV Cost

Where:

NPV $=$ Net Present Value

PV Benefit $=$ discount factor $\mathrm{x}$ Benefit

PV Cost $=$ discount factor $\mathrm{x}$ Cost

c. Internal Rate of Return (IRR)

$$
\mathrm{IRR}=\mathrm{i}_{1}+\frac{N P V_{1}}{N P V_{1}-N P V_{2}}\left(\mathrm{i}_{2}-\mathrm{i}_{1}\right) .(7)
$$

Where:

$\mathrm{i}_{1}=$ the highest discount factor that still gives positive NPV

$\mathrm{i}_{2}=$ the lowest discount factor that still gives negative NPV

$\mathrm{NPV}_{1}=$ Net Present Value Positive

$\mathrm{NPV}_{2}=$ Net Present Value Negative

d. Break Event Point (BEP):

$$
\begin{aligned}
& \mathrm{BEP} \text { Unit }=\frac{\mathrm{FC}}{\mathrm{Hy}-\mathrm{VC}} \\
& \text { BEP Values }=\frac{\mathrm{FC}}{1-\frac{\mathrm{VC}}{\mathrm{Hy}}}
\end{aligned}
$$

Where:

BEP $=$ Break Event Point of production (Unit or Rap)

$\mathrm{FC}=$ Fixed cost or investment (Rap)

$\mathrm{VC}=$ Variable or operational cost (Rap/Unit)

Hay $=$ Sold cost $($ Rap/Unit $)$

e. Sensitivity Analyses:

$$
S V=P x \frac{N P V^{+}}{\left(N P V^{+}\right)-\left(N P V^{-}\right)} \ldots \ldots
$$

Where:

$\mathrm{SV}=$ Switching value

$\mathrm{P}=$ changing cost/benefit which indicating negative NPV 
$\mathrm{NPV}^{+}=$project NPV before changing

$\mathrm{NPV}^{-}=$project $\mathrm{NPV}$ after changing

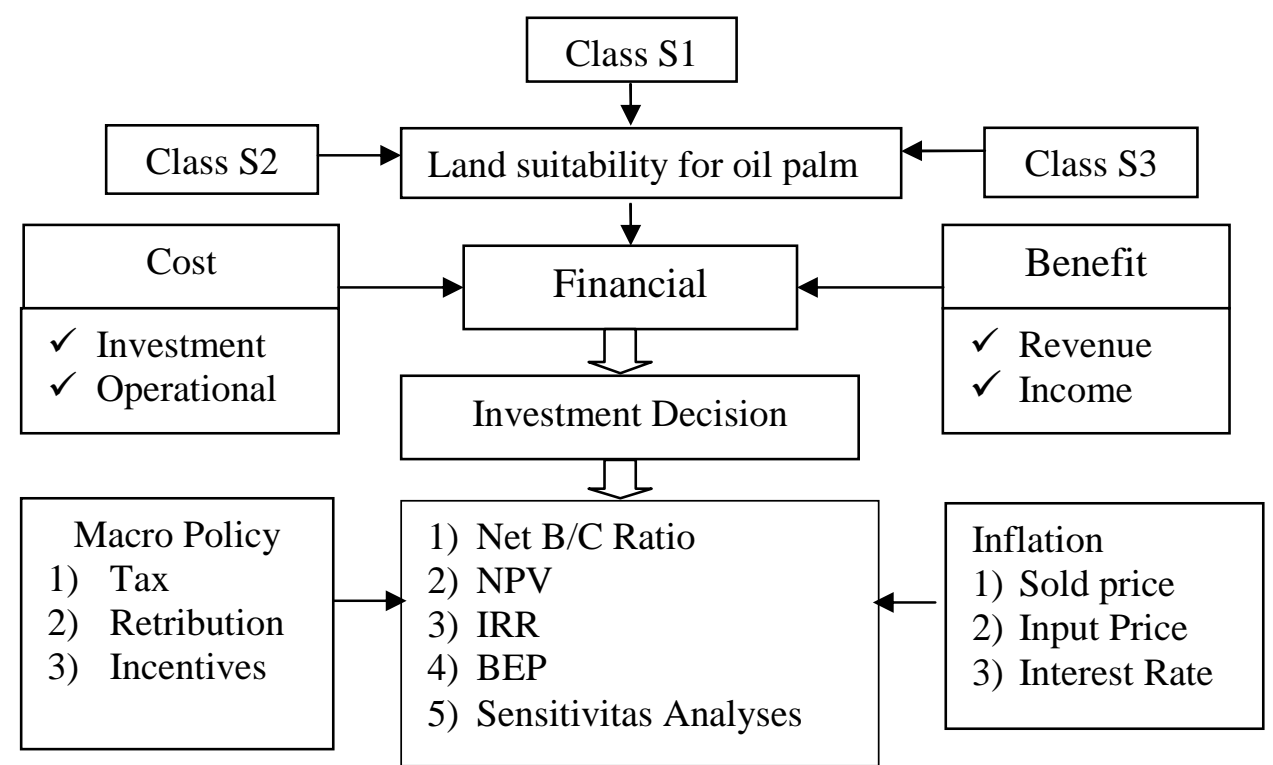

Figure 1. The research flow chart

\section{RESULTS AND DISCUSSION}

\section{Land Suitability for Oil Palm Plantation}

Most of the wetlands in study area are classified as very suitable $\left(\mathrm{S}_{1}\right)$ consists of several area far away from the rivers. Type 2 levels (suitable, $S_{2}$ ) are found in nearly the entire areas near to the rivers. As for the classification of Type 3 level $\left(S_{3}\right)$ classified as marginal land $\left(\mathrm{S}_{3}\right)$ for oil-palm is very little found. Levels for land suitability is presented in Table 1. Based on Table 1, the potential land for development of oil palm can be further elaborated in the form of high potential, medium potential and low potential, which is explained as the following (Armanto et al., 2013):

1) Highly potential land has land suitability classes for oil palm, $75 \%$ is classified suitable and $<25 \%$ belongs to marginally suitable.

2) Moderately potential land has land suitability classes for oil palm, $25-50 \%$ is classified suitable and 50-75\% belongs to marginally suitable.

3) Lowly potential land has land suitability classes for oil palm, 50-75\% belongs to marginally suitable and $25-50 \%$ is classified as not suitable.
At this timethe high-potential lands are highly available which covering areas of about 8,701 ha or $52.10 \%$ of the whole areas, which is verylikely to be developed, so we expect that development ofoil palm plantationstaking into accountthe land suitability can show maximum production. Theoretically it was field recorded that high potentialsuitability of landcan produce morethan 24tons of FFBperha/year. For someareas with suitable level $\left(\mathrm{S}_{2}\right)$ covers around 2,554 ha $(15.29 \%)$ which are able to produce19-24tons of FFB perha/year.As for areas of moderate to low potential which have some limiting factors for the development of oil palm, namely(Armantoet al., 2013):

1) The roots condition (r) that includes inhibiting factors, namely soil drainage class, soil texture and rooting depth. Rooting depth is an indicator for effectively shallow depth of soils, especially in areas with high pyrite content and poor drainage,

2) Holding capacity of soil nutrients (f), which include inhibiting factor is the CEC (cation exchange capacity) and soil $\mathrm{pH}$,

3) Poisoning (x), which include inhibiting factor is the salinity,

4) Existence of potential acidic sulfate soil. 
The lower potential suitability means it needs more input to make the land becomes

suitable for the growth and development of oil palm.

Table 1. Potency of land suitability for oil palm plantations

\begin{tabular}{lllccc}
\hline $\mathrm{Nr}$ & $\begin{array}{c}\text { Potency of land } \\
\text { suitability }\end{array}$ & \multicolumn{1}{c}{ Land Suitability Class } & $\begin{array}{c}\text { Acreages } \\
(\mathrm{ha})\end{array}$ & $\begin{array}{c}\text { Percentage } \\
(\%)\end{array}$ & $\begin{array}{c}\text { FFB Yield */ } \\
\text { ton/ha/year) }\end{array}$ \\
\hline 1. & High potency & very suitable $\left(\mathrm{S}_{1}\right)$ & 8,701 & 52.10 & $>24$ \\
& $\left(\mathrm{~S}_{1}, \mathrm{~S}_{2}\right)$ & suitable $\left(\mathrm{S}_{2}\right)$ & 2,554 & 15.29 & $19-24$ \\
2. & Middle potency & suitable $\left(\mathrm{S}_{2}\right)$ & 2,150 & 12.87 & $19-24$ \\
& $\left(\mathrm{~S}_{2}, \mathrm{~S}_{3}\right)$ & marginally suitable $\left(\mathrm{S}_{3}\right)$ & 1,233 & 7.39 & $13-18$ \\
3. & Low potency $\left(\mathrm{S}_{3}\right)$ & marginally suitable $\left(\mathrm{S}_{3}\right)$ & 2,062 & 12.35 & $13-18$ \\
4. & No potency $(\mathrm{N})$ & temporary not suitable $\left(\mathrm{N}_{1}\right)$ & 0 & 0.00 & $<12$ \\
& & permanently not suitable $\left(\mathrm{N}_{2}\right)$ & 0 & 0.00 & Very low \\
\hline
\end{tabular}

FFB : Fresh Fruit Bunch

Source : */ Land suitability is based on topographic maps (scale 1:50.000), landsat imaginary analyses (2010), soil maps, geology maps, field observations and laboratory analyses (2013)

Table 2. Oil palm costs in wetlands based on land suitability class $(10,000$ ha)

\begin{tabular}{|c|c|c|c|c|c|c|c|}
\hline \multirow[t]{2}{*}{$\mathrm{Nr}$} & \multirow[t]{2}{*}{ Component } & \multicolumn{2}{|l|}{$\mathrm{S}_{1}$} & \multicolumn{2}{|l|}{$\mathrm{S}_{2}$} & \multicolumn{2}{|c|}{$\mathrm{S}_{3}$} \\
\hline & & $\begin{array}{c}\text { Total } \\
\text { (Rp billion) }\end{array}$ & $\%$ & $\begin{array}{c}\text { Total } \\
\text { (Rp billion) }\end{array}$ & $\%$ & $\begin{array}{c}\text { Total } \\
\text { (Rp billion) }\end{array}$ & $\%$ \\
\hline & Investment cost & & & & & & \\
\hline a. & Plants & 159.69 & 83.83 & 159.69 & 83.83 & 159.69 & 83.83 \\
\hline b. & Non plants & 3.61 & 1.89 & 3.61 & 1.89 & 3.61 & 1.89 \\
\hline c. & Land & 16.00 & 8.40 & 16.00 & 8.40 & 16.00 & 8.40 \\
\hline & Property (HGU) & 11.20 & 5.88 & 11.20 & 5.88 & 11.20 & 5.88 \\
\hline & Total investment cost & 190.50 & 100.00 & 190.50 & 100.00 & 190.50 & 100.00 \\
\hline 2 & Operational cost/year & & & & & & \\
\hline a. & Maintenance cost & 29.92 & 69.06 & 29.92 & 70.94 & 29.92 & 74.94 \\
\hline & General/administration & 3.98 & 9.16 & 3.98 & 9.41 & 3.98 & 9.94 \\
\hline & Transport cost & 8.83 & 20.39 & 7.60 & 18.21 & 5.43 & 13.61 \\
\hline & Depreciationcost & 0.61 & 1.40 & 0.61 & 1.44 & 0.61 & 1.52 \\
\hline & Total operational cost & 43.32 & 100.00 & 42.17 & 100.00 & 39.92 & 100.00 \\
\hline
\end{tabular}

To soil class of $\mathrm{N}$ (not suitable), then the constraints are permanent and very difficult to be reclaimed or require a very high cost. Based on the character of both physical and chemical properties, the research location does not have soils that belong to not suitable N (Table 1).

\section{Financial Feasibility Analysis}

Oil palm projects need investment and operational costs. Investment cost is dominated by not productive plant (TBM) and operating costs cover dominantly productive plants (TM). Investment costs are accounted for a plant cycle (ca30 years). The investment and operating costs are presented in Table 2.

The biggest investment cost was for plants, especially for new plant (TB) and not TBM which covered Rp 159.69 billion
$(83.83 \%)$. Operating costs was found maximally for maintenance costs amounting to $69.06 \%$ ( $R p 29.92$ billions). For this research the selling price of FFB Rp 1,800,$/ \mathrm{kg}$ was calculated as unchanged, net income after taxes was obtained for each class of land suitability (S1, S2 and S3), which is an average per year to Rp 299.68 billion for the $\mathrm{S}_{1}$ class, $\mathrm{Rp} 255.68$ billion for the class $\mathrm{S}_{2}$ and $\mathrm{Rp} 168.54$ billion for the $\mathrm{S}_{3}$ class (Table 3 ).

Based on Table 3 that land suitability classes $\mathrm{S}_{1}$ (very suitable) contributed the highest income compared with those of class $\mathrm{S}_{2}$ (suitable) and class $\mathrm{S}_{3}$ (marginally suitable). The lower classes of land suitability is, lower revenues and income is earned.

Feasibility analysis cover some parameters, namely Net B/C Ratio (Benefit Cost Ratio), NPV (Net Present Value) and 
IRR (Internal Rate of Return) and take into account how much the volume of production that generate break even (no profit and no loss) with the technique of calculating the value of BEP (Break Event Point).

Table 3. Average revenue and income in wetlands based on land suitability class

\begin{tabular}{llccc}
\hline \multirow{2}{*}{} & \multicolumn{1}{c}{ Components } & \multicolumn{3}{c}{ Total (Rp billion/year) } \\
\cline { 3 - 4 } & & $\mathrm{S}_{1}$ & $\mathrm{~S}_{2}$ & $\mathrm{~S}_{3}$ \\
\hline 1. & Average revenue per year & 382.15 & 332.31 & 235.04 \\
2. & Average net income (Net Benefit) per year & 299.68 & 255.68 & 168.54 \\
\hline
\end{tabular}

Table 4. Net B/C ratio and NPV of oil palm plantation based on land suitability class

\begin{tabular}{|c|c|c|c|c|c|c|c|}
\hline \multirow[t]{2}{*}{$\mathrm{Nr}$} & \multirow[t]{2}{*}{ Details } & \multicolumn{6}{|c|}{ Total } \\
\hline & & $\mathrm{S}_{1}$ & $\mathrm{~S}_{2}$ & $\mathrm{~S}_{3}$ & $\begin{array}{l}\text { Different } S_{1} \\
\text { with } S_{2}(\%)\end{array}$ & $\begin{array}{l}\text { Different } S_{1} \\
\text { with } S_{3}(\%)\end{array}$ & $\begin{array}{l}\text { Different } S_{2} \\
\text { with } S_{3}(\%)\end{array}$ \\
\hline 1. & $\Sigma$ PV Net B (billion Rp) & $1,341.98$ & $1,087.59$ & 759.80 & 18.96 & 43.38 & 30.14 \\
\hline 2. & $\Sigma$ PV Net C (billion Rp) & 348.91 & 342.54 & 334.29 & 1.82 & 4.19 & 2.41 \\
\hline 3. & Net B/C Ratio & 27.57 & 22.35 & 15.61 & 18.93 & 43.38 & 30.16 \\
\hline 4. & NPV & 242.79 & 182.08 & 116.79 & 25.00 & 51.90 & 35.86 \\
\hline
\end{tabular}

\section{Net B/C Ratio and NPV}

Table 4 shows that the oil palm plantations for the three classes of land suitability, each feasible to be executed where $\mathrm{Net} \mathrm{B} / \mathrm{C}$ ratio is $\geq 1$. Land suitability class $S_{1}$ is greater than $\mathrm{S}_{2}(18.96 \%)$ and $(43.38 \%)$ greater than the $\mathrm{S}_{3}$, while the $\mathrm{S}_{2}$ class is $30.14 \%$ greater than the $\mathrm{S}_{3}$ class. So priority order is recommended for land suitability class S1 and then followed by the class $S_{2}$ and class $S_{3}$. Net Present Value (NPV) of oil palm plantation for three land suitability class is positive. It means that oil palm plantation project in the three classes is feasible to be conducted. The highest benefits is obtained in class $S_{1}(R p 242.79$ billion) and has the highest difference of $51.90 \%$ with those of the class $\mathrm{S}_{3}$. This is related to the difference between the productivity of the land suitability classes significantly (Table 4).

\section{IRR (Internal Rate of Return)}

The positive IRR figure for oil palm plantation was found where the IRR is far beyond the value of the expected rate of return, i.e. respectively by $74.17 \%$ for the classes $S_{1}$, IRR for class $S_{2}$ is $66.82 \%$ and $58.63 \%$ for class $S_{3}$. Class $S_{1}$ are the most prospective for oil palm development because it will provide the highest return on capital the by a margin of $7.36 \%$ to $20.95 \%$ of the $S_{2}$ and $\mathrm{S}_{3}$ (Table 5). By considering the three eligibility criteria that have been obtained by the value of Net B/C ratio, NPV and IRR for oil palm plantations in wetlands, financially it can be concluded that the oil palm plantations in the all classes (category) are suitable to be carried out.

\section{BEP (Break Even Points)}

BEP calculation is given in Table 6. Based on Table 6 , of the three classes of land suitability, which resulted in the BEP of production at the lowest value is for class $S_{1}$, this means that the class $\mathrm{S} 1$ that produces the fastest Expected Rate of Return. By obtaining the value of BEP, then the investor can determine how big the scale of operation of oil palm plantations that can produce the Expected Rate of Return quicker. If information about the scale of operations can be clearly known, it is possible there will be an increase in the flow of investment and opportunities to expand business scale can also be performed. 
Table 5. IRR for oil palm plantations in wetlands based on land suitability class

\begin{tabular}{|c|c|c|c|c|c|c|c|}
\hline \multirow[t]{2}{*}{$\mathrm{Nr}$} & \multirow[t]{2}{*}{ Details } & \multicolumn{6}{|c|}{ Total } \\
\hline & & $\mathrm{S}_{1}$ & $\mathrm{~S}_{2}$ & $\mathrm{~S}_{3}$ & $\begin{array}{c}\text { Different } \\
S_{1} \text { with } S_{2} \\
\end{array}$ & $\begin{array}{c}\text { Different } \\
S_{1} \text { with } S_{3} \\
\end{array}$ & $\begin{array}{l}\text { Different } \\
S_{2} \text { with } S_{3}\end{array}$ \\
\hline 1. & Expected Rate of Return & 16.00 & 16.00 & 16.00 & -- & -- & -- \\
\hline 2. & IRR & 74.17 & 66.82 & 58.63 & 7.36 & 20.95 & 12.26 \\
\hline
\end{tabular}

Table 6. BEP operation of oil palm plantations in wetlands based on land suitability class

\begin{tabular}{clcccccc}
\hline $\mathrm{Nr}$ & \multicolumn{1}{c}{ Category } & \multicolumn{3}{c}{ BEP } & \multicolumn{3}{c}{ Different $(\%)$} \\
\cline { 3 - 7 } & & Class S1 & Class S2 & Class S3 & $\mathrm{S}_{1}$ with $\mathrm{S}_{2}$ & $\mathrm{~S}_{1}$ with $\mathrm{S}_{3}$ & $\mathrm{~S}_{2}$ with $\mathrm{S}_{3}$ \\
\hline 1. & BEP (billions Rp) & 213.80 & 216.97 & 227.68 & 1.46 & 6.10 & 4.70 \\
2. & $\begin{array}{l}\text { BEP Production unit } \\
\text { (million kg) }\end{array}$ & 117.13 & 118.64 & 123.70 & 1.31 & 5.31 & 4.09 \\
\hline
\end{tabular}

Table 7. Sensitivity analysis assuming a $15 \%$ increase in maintenance costs

\begin{tabular}{llcccccc}
\hline $\mathrm{Nr}$ & \multicolumn{1}{c}{ Category } & \multicolumn{3}{c}{ Values } & \multicolumn{3}{c}{ Different (\%) } \\
\cline { 3 - 7 } & & Class S1 & Class S2 & Class S3 & $\mathrm{S}_{1}$ with $\mathrm{S}_{2}$ & $\mathrm{~S}_{1}$ with $\mathrm{S}_{3}$ & $\mathrm{~S}_{2}$ with $\mathrm{S}_{3}$ \\
\hline 1. & Net B/C Ratio & 27.23 & 22.00 & 18.47 & 19.21 & 32.17 & 16.05 \\
2. & NPV (billion Rp) & 239.19 & 178.48 & 53.77 & 25.30 & 77.52 & 69.87 \\
3. & IRR (\%) & 73.79 & 66.38 & 44.01 & 10.04 & 40.36 & 33.70 \\
\hline
\end{tabular}

\section{Sensitivity Analysis}

Sensitivity analysis is commonly performed by changing the component costs of maintenance, production and selling price of FFB (fresh fruit bunch). In this analyses, $15 \%$ increase in maintenance costs per year is determined as adjusted for inflation. Basic considerations for the use of the maintenance cost is due to this cost component is the largest component in the operational costs expended on a regular basis each year. Based on the sensitivity analysis assuming a 15\% increase in maintenance costs is presented in Table 7.

From Table 7 it appears that the increase of $15 \%$ in maintenance costs do not result in meaningful change. Oil palm plantations for the three classes of land suitability is still feasible to be conducted. The main priority remains investing decisions on land suitability class $\mathrm{S} 1$ which having Net $\mathrm{B} / \mathrm{C}$ ratio, NPV and IRR are the highest and followed by class $\mathrm{S}_{2}$. If it is assumed that FFB production decreased by $15 \%$, the sensitivity analyses can be seen in Table 8 .

When production decreased, it does not make the business is not feasible, but it reduced net income and IRR is going down an average of $9.85 \%$ for classes $S_{1}, S_{2}$ class fell to an average of $10.25 \%$ and dropped an average of $19.58 \%$ for the class $\mathrm{S}_{3}$.

Sensitivity analysis with a selling price of FFB to be down by $5 \%$ is still making an effort to keep the business going on. Sensitivity analysis assuming a decrease of 5 $\%$ on the selling price of FFB is given in Table 9. If we assume a decrease of $5 \%$ on the selling price of FFB, the biggest difference between the classes of land suitability in NPV is for difference of the class $S_{1}$ with $S_{3}$ class, namely $48.62 \%$.

This means a decrease in the selling price of FFB sensitivity is very influential on gaining of net income. But overall the results of a sensitivity analysis of various factors, oil palm plantations on wetlands for the three classes of land suitability $\left(S_{1}, S_{2}\right.$ and $\left.S_{3}\right)$ are financially feasible for established and developed, so that the decision is in accordance with the capital investment required for the development of oil palm plantation. 
Table 8. Sensitivity analysis assuming a $15 \%$ decline in FFB production

\begin{tabular}{llcccccc}
\hline $\mathrm{Nr}$ & \multicolumn{1}{c}{ Category } & \multicolumn{3}{c}{ Values } & \multicolumn{3}{c}{ Different (\%) } \\
\cline { 3 - 7 } & & Class S1 & Class S2 & Class S3 & $\mathrm{S}_{1}$ with $\mathrm{S}_{2}$ & $\mathrm{~S}_{1}$ with $\mathrm{S}_{3}$ & $\mathrm{~S}_{2}$ with $\mathrm{S}_{3}$ \\
\hline 1. & Net B/C Ratio & 22.42 & 17.99 & 15.09 & 19.76 & 32.69 & 16.12 \\
2. & NPV (billions Rp) & 183.45 & 132.05 & 27.18 & 28.02 & 85.19 & 79.42 \\
3. & IRR (\%) & 66.87 & 59.97 & 40.70 & 10.32 & 39.14 & 32.13 \\
\hline
\end{tabular}

Table 9. Sensitivity analysis assuming a decrease of $5 \%$ on the selling price of FFB

\begin{tabular}{llcccccc}
\hline $\mathrm{Nr}$ & \multicolumn{1}{c}{ Category } & \multicolumn{3}{c}{ Values } & \multicolumn{3}{c}{ Different (\%) } \\
\cline { 3 - 7 } & & Class S1 & Class S2 & Class S3 & $\mathrm{S}_{1}$ with $\mathrm{S}_{2}$ & $\mathrm{~S}_{1}$ with $\mathrm{S}_{3}$ & $\mathrm{~S}_{2}$ with $\mathrm{S}_{3}$ \\
\hline 1. & Net B/C Ratio & 25.86 & 20.90 & 14.99 & 19.18 & 42.03 & 28.28 \\
2. & NPV (billions Rp) & 223.01 & 165.41 & 114.59 & 25.83 & 48.62 & 30.72 \\
3. & IRR (\%) & 71.82 & 64.61 & 59.12 & 10.04 & 17.68 & 8.50 \\
\hline
\end{tabular}

\section{CONCLUSIONS}

Land productivity and input amount will determine some differences of each soil suitability $\left(\mathrm{S}_{1}, \mathrm{~S}_{2}\right.$ and $\left.\mathrm{S}_{3}\right)$. The more land suitability level is, the more Fresh Fruit Bunches of Oil Palm (FFB) productivity per ha is produced and the less input is given. Net B/C Ratio, NPV and IRR for all land suitability classes are financially feasible for oil palm plantation development, however the most feasible and the most Expected Rate of Return (IRR) is in tidal wetlands with $S_{1}$ land suitability (very suitable), followed by $S_{2}$ (suitable) and $\mathrm{S}_{3}$ (marginally suitable). Sensitivity analysis to feasibility for three land suitability is still economically feasible to build and to develop oil palm plantation, especially in large scale, thus its decision for capital investment is suitable.

\section{ACKNOWLEDGEMENTS}

The authors wish to acknowledge the financial supports provided through doctorate BPPS scholarship 1999-2013 by Directorate General for Higher Education, Ministry of National Education, Indonesia.

\section{REFERENCES}

Armanto, M.E., M.A. Adzemi, E. Wildayana and M.S. Imanudin. 2013. Land Evaluation for Paddy Cultivation in the Reclaimed Tidal Lowland in Delta Saleh, South Sumatra, Indonesia.
Journal of Sustainability Science and Management. Vol8(1):32-42.

Soil Survey Staff. 2014. Soil Survey Field and Laboratory Methods Manual. Soil Survey Investigations Report No. 51 Version 2.USDA, Washington DC.

Wildayana, E. 2013. Analisis Perilaku Petani Kelapa Sawit dalam Kaitannya dengan Prospek Keberlanjutan Kebun Plasma di Sumatera Selatan. Disertasi. Program DoktorIlmu-IlmuPertanian,

FakultasPertanianUnsri. Palembang.

Wildayana, E., Imron Zahri, Andy Mulyanaand Laila Husin. 2012. The Analyses Structure and Household Income Distribution of Palm Oil (ElaeisguineensisJacq) Farmers NESTRANS in South Sumatra, Indonesia. Proc of UMT $11^{\text {th }}$ International Annual Symposium on Sustainability Science and Management, 09-11 ${ }^{\text {th }}$ July 2012, p. 1480-1487, Malaysia. 